\title{
Ocupação do solo e ilha de calor noturna em avenidas marginais a um córrego urbano
}

\author{
Land occupation and nocturnal heat islands in avenues \\ that border an urban stream
}

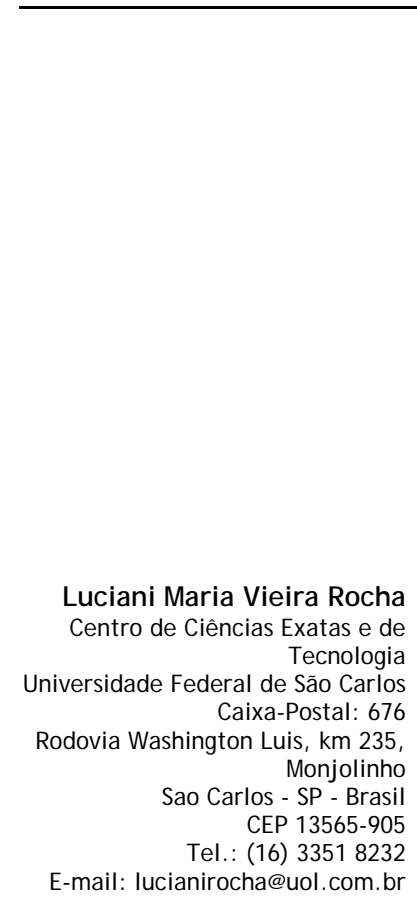

\section{Luciani Maria Vieira Rocha \\ Léa Cristina Lucas Souza \\ Francisco J osé Vigeta Castilho}

\section{Resumo}

$\mathbf{E}$

ste artigo trata da influência da morfologia urbana na temperatura do ar ao longo das avenidas Alberto Andaló e José Munia, em São José do

Rio Preto. Quatro pontos dessas avenidas, ambas situadas ao longo do

Córrego Canela, foram selecionados como pontos de coleta de dados de temperatura do ar. Os resultados revelaram que há diferenças de temperaturas entre os pontos. Foram utilizados mapas contendo dados cadastrais e morfológicos, tais como levantamento topográfico, uso e ocupação do solo, configuração das quadras e lotes, altura das edificações e cobertura do solo, obtidos da Prefeitura ou por imagem de satélite e observações de campo. A relação dos dados com as características de uso e ocupação do solo demonstrou uma influência significativa da presença de vegetação e permeabilidade do solo na diminuição da temperatura do ar noturna e, consequentemente, minimização das ilhas de calor. Também se verificou que as áreas com maior ocupação com construções e com maior pavimentação nas ruas e quadras perderam menos calor, levando à formação de ilhas de calor noturnas mais intensas.

Palavras-chave: Vegetação e clima. Morfologia urbana. Clima urbano e ilhas de calor.

\section{Abstract}

Léa Cristina Lucas Souza Centro de Ciências Exatas e de Tecnologia

Universidade Federal de São Carlos Tel.: (16) 33518232 E-mail: leacrist@ufscar.br

Francisco J osé Vigeta Castilhos

Centro de Ciências Exatas e de Tecnologia

Universidade Federal de São Carlos Tel.: (16) 33518232 E-mail: francisco-vigeta@ig.com. br

Recebido em 22/12/10

This paper discusses the influence of urban morphology on air temperatures along the avenues Alberto Andaló and José Munia, in São José do Rio Preto. Four places in those avenues were chosen for thermal data collection - both are located along the Canela stream,. The results revealed temperature differences between the four points. The study used maps containing cadastra and morphological data, such as land use, topography, configuration of blocks and lots, building heights and ground cover, either developed by the local authority or obtained from satellite imagery and field observation. The relationships between these data and the characteristics of land use and occupation showed a significant decrease in air temperatures during the night, due to the presence of vegetation and soil permeability, reducing heat islands. Conversely, areas with high occupancy of buildings and intensely paved areas and blocks lost less heat, leading to the formation of the highest urban heat islands during the night period.

Aceito em 05/07/11 


\section{Introdução}

O sistema viário tem sido tratado prioritariamente como espaço dos automóveis, não se considerando, na maior parte das vezes, o nível de conforto humano no ambiente externo. A proteção às condições climáticas extremas ou à qualidade dos passeios não é comum no cotidiano do pedestre. Além disso, em muitos casos, as vias públicas tomaram o lugar das várzeas dos cursos d’água na ocupação e expansão urbana, ou então foram construídas sobre eles. No Brasil, a relação com o território, espaço natural sobre o qual se assenta a cidade, foi, em geral, a de desprezar a existência de rios, córregos, a presença de vegetação, bem como a topografia do lugar e suas características climáticas.

De acordo com Dacanal et al. (2008), os fundos de vale em área urbana interferem no clima, e, quando vegetados, proporcionam a formação de microclima mais úmido e com menor temperatura. Quando são canalizados, têm sua vegetação natural suprimida, apresentam suas margens ocupadas com grande adensamento e deixam de favorecer a diminuição da temperatura do ar e a condução do ar fresco ao longo dos vales ou através deles.

As áreas urbanizadas produzem efeitos na atmosfera da camada intraurbana de uma região devido às diversas formas de uso e ocupação do solo e estrutura urbana. O grau de transformação das superfícies, os materiais utilizados, a rugosidade, a densidade, a permeabilidade do solo, a contaminação do ar e a geração local de calor são fatores que irão determinar a reflexão, absorção ou armazenamento de calor, além de produzir efeitos na circulação e atrito da ventilação. A diferença de resposta térmica entre o ambiente urbano e o rural é principalmente marcada pelo desenvolvimento de ilhas de calor nas áreas urbanas. Parker (2010) esclarece que as ilhas de calor são resultados das propriedades físicas dos edifícios e de outras estruturas. Além disso, ocorre a emissão de calor pelas atividades humanas, existindo também, frequentemente, a formação de ilhas de frio em parques e em regiões menos adensadas.

O comportamento térmico urbano altera-se à medida que a morfologia dos espaços é alterada. Com o aumento de impermeabilização e a verticalização, haverá mais superfícies acumuladoras de calor e será menor a porção de céu visível. Isso faz com que se acumule o calor absorvido e diminua a dissipação do calor dos ambientes. Portanto, a melhor geometria para o conforto térmico do espaço urbano é um difícil equilíbrio entre a ocupação do espaço urbano e a obstrução do céu. Se, por um lado, uma maior ocupação e verticalização com menor porção visível do céu diminui a perda de calor durante a noite, por outro, propicia sombreamento durante o dia. Menores densidades construídas, baixa verticalização e maior porção de céu visível possibilitam maior tempo de acesso solar, fazendo com que os ambientes mais abertos recebam maior quantidade de radiação direta incidente durante o dia (SOUZA et al., 2009).

Scussel e Sattler (2010) procuraram avaliar o impacto da verticalização e do adensamento na qualidade do espaço residencial de Porto Alegre. Afirmam que o processo de substituição de edificações por outras de maior porte e altura imprime nova volumetria à conformação da área urbanizada. Segundo os autores, os aumentos da taxa de ocupação dos terrenos, do índice de aproveitamento e das alturas máximas permitidas, além de incrementarem o trânsito, estabelecem novas relações de luz e sombra, reordenando as áreas livres e modificando a paisagem, o que leva ao desconforto dos moradores.

Os benefícios do sombreamento em equilíbrio, com a menor perda de calor por obstrução da dissipação, são apontados por Emmanuel (2005) como solução de controle da incidência solar para amenizar as ilhas de calor urbanas. O autor afirma que as áreas expostas ao sol, sendo pavimentadas ou não, apresentam pouca diferença ante a radiação. Complementa ainda que as áreas sombreadas por árvores ou edificações, da mesma forma, têm comportamento semelhante sob ação da insolação. Porém, enfatiza a vantagem do sombreamento obtido pelo uso de arborização, já que os elementos construídos não absorvem a radiação interceptada.

Apesar das considerações feitas por Emmanuel (2005) para o período de insolação diurna, há que se levar em conta também que em alguns casos podem ser constatadas temperaturas noturnas mais elevadas em áreas vegetadas do que em áreas mais abertas. Isso pode ser verificado em Barbosa, Barbirato e Vecchia (2003), que constataram que o efeito da vegetação foi de reter calor em uma das áreas analisadas. Essa retenção ocorre devido ao grupamento de caráter homogêneo e com densidade das copas, que, em seu conjunto, trabalha como uma barreira das correntes de ar. Naquele estudo, os melhores desempenhos da vegetação como amenizador de temperatura foram observados em uma praça, onde a constituição da vegetação de forma heterogênea e com copas não muito densas apresentou temperatura mais amena.

A partir de resultados obtidos em pesquisas sensoriais e climáticas, Silva e Romero (2009) 
concluíram que a quantidade de superfície impermeável e a quantidade de superfície sombreada são determinantes para a criação de microclimas diferenciados. Nessa pesquisa realizada em ruas da cidade de Teresina, os autores verificaram que aquelas alterações ocorrem principalmente pela quantidade e conformação da arborização que possuem.

Avaliando a influência de indivíduos arbóreos na temperatura do ar e umidade relativa do ar na cidade de Campinas, Abreu e Labaki (2010) concluíram que todas as espécies foram capazes de alterar a sensação de conforto térmico no entorno imediato. As espécies perenes demonstraram maior influência na sensação térmica no período de verão do que no inverno, com condições mais confortáveis à sombra da copa da árvore durante as duas estações. As decíduas proporcionaram boas condições de conforto em diferentes distâncias durante o ano.

O papel da vegetação na mitigação da elevação das temperaturas urbanas foi também constatado por Gomes e Lamberts (2009) em estudo realizado em Montes Claros, MG. Naquele estudo foi verificado que o aumento da cobertura vegetal é acompanhado por uma diminuição da temperatura, com diferenças mais significativas no período noturno. O aumento das áreas impermeáveis (calçadas, ruas pavimentadas e asfaltadas) e maior densidade construída acompanham o aumento da temperatura devido à diminuição das trocas térmicas de calor latente. A diminuição de áreas verdes reduz a perda de calor pelo processo de evapotranspiração, enquanto a maior massa construída contribui para atrasar a perda de calor. Segundo os autores, as diferenças de comportamento térmico entre as áreas estudadas devem ser atribuídas a uma associação das variáveis do ambiente. Como o clima urbano é um sistema aberto, a tendência de aumento térmico em determinada área pode ser compensada mediante alterações nos ventos e estoque de calor, ou por sombreamento durante o dia.

Chen-Yi et al. (2009) demonstram uma clara relação entre a geometria do desenho urbano e a temperatura do ar em ruas de Taiwan, ao combinar os parâmetros ambientais que influenciam o ambiente térmico. Os autores verificaram que as temperaturas noturnas mais baixas ocorreram em lugares com baixa densidade de construção e alta taxa de vegetação. Durante o dia, a relação entre a temperatura do ar e a densidade da vegetação não foi significativa. Explicam ainda que isso ocorreu porque nesse período a temperatura do ar foi fortemente influenciada pela presença de asfalto, radiação, sombra e tráfego.
O comportamento térmico entre áreas adensadas situadas no centro da cidade de Tel-Aviv (Israel) e em áreas com pouca ocupação às margens da cidade foi comparado por Saaroni et al. (2000). Os autores encontraram diferenças mais significativas também no período noturno, devido ao arrefecimento rápido das áreas mais afastadas da ocupação urbana. Também verificaram diferenças na resposta térmica entre áreas no centro da cidade com diferentes usos e ocupação do solo. Mapas de isotermas indicaram que maior presença de asfalto, maior tráfego e padrões de construção mais adensados contribuíram para que algumas áreas acumulassem mais calor. Como características urbanas com efeito de resfriamento e amenização das altas temperaturas, foram apontados a presença de vegetação, principalmente pela promoção de sombreamento, e parques e áreas mais abertas, uma vez que facilitam a penetração da brisa do mar.

Também considerando a importante influência da vegetação nas condições térmicas, Duarte (2009) propõe um indicador para o planejamento urbano, que relaciona arborização, densidade e superfícies d’água.

Na abordagem do clima em áreas urbanas, Oke (2006) propõe que a escala local seja estudada a partir de uma área dentro da cidade que possua características semelhantes de desenvolvimento. Essa área pode ser um bairro com densidade homogênea ou mesma altura dos edifícios, que sofrem a influência de um conjunto de microclimas. Uma abordagem em microescala procura estudar os microclimas gerados a partir da influência de um edifício, de uma rua ou de árvores, alcançando uma pequena área do entorno.

Adotando uma abordagem em microescala, este artigo relata o estudo feito com o objetivo de verificar a interação entre temperatura do ar e caracterização do ambiente urbano. Para esse fim são analisadas áreas com distintos padrões de ocupação ao longo do Córrego Canela, na cidade de São José do Rio Preto, SP. São descritas a seguir a área selecionada e a metodologia aplicada, apresentando-se na sequência os resultados encontrados e as principais considerações.

\section{Metodologia}

A metodologia aplicada baseia-se nas etapas de seleção de pontos amostrais na área de estudo, na caracterização morfológica do entorno urbano, na coleta de dados térmicos e na análise de correlação entre parâmetros térmicos e urbanos.

A caracterização morfológica do entorno urbano dos pontos amostrais e a coleta de dados térmicos 
de temperatura do ar objetivaram estabelecer parâmetros para comparação entre os dois trechos do córrego.

Para a análise morfológica, considerou-se uma área com $100 \mathrm{~m}$ de raio de influência a partir de cada ponto. O cálculo de áreas construídas e demais áreas para o estudo foi estimado a partir de imagens de satélite do Google Earth, mediante a elaboração de desenhos digitais sobre a planta de quadras e lotes.

Para verificar a tendência de queda ou o aumento da temperatura e a variação no grau de influência das características da superfície das áreas de estudo, realizou-se uma análise da relação entre as variáveis e cobertura do solo e a temperatura do ar.

\section{Área de estudo e seleção de pontos amostrais}

A área de estudo situa-se na cidade de São José do Rio Preto, no interior paulista, a 489 m de altitude, 2049'11” latitude sul, 49²2'46” longitude oeste. Possui clima tropical de altitude (Cwa, segundo a classificação de Koppen), com inverno seco e ameno. Sua temperatura média anual é de $25,4{ }^{\circ} \mathrm{C}$ (com temperatura média do mês mais frio superior a $\left.18^{\circ} \mathrm{C}\right)$.

Segundo Castilho (2006), os totais de chuvas anuais sofrem grande variação, de forma irregular, em função de interferências atmosféricas regionais. Também no período de um ano há uma grande variação pluviométrica, sendo considerado o período de dezembro a março como extremamente chuvoso, e o período de junho a agosto como extremamente seco. Com relação à temperatura, o autor aponta o período chuvoso de verão, que vai de outubro a março, como sendo o dos meses mais quentes. Já o período mais seco, de inverno, que vai de maio a agosto, apresentando uma relativa queda na temperatura.

Localizada na região noroeste do Estado de São Paulo, sede da $8^{\mathrm{a}}$ região administrativa (Figura 1 ), a cidade se destaca pelos serviços de alcance regional que oferece, sobretudo nas áreas da saúde e educação. Com uma população em torno de 400.000 habitantes, é um polo regional com comércio denso e diversificado. Atrai consumidores dos bens e serviços oferecidos, bem como trabalhadores empregados no município, o que tem implicado em elevadas taxas de crescimento anual ao longo das últimas décadas.

Quanto às vias urbanas, avenidas em fundo de vale são importantes eixos do sistema viário de Rio Preto. Como resultado do processo histórico, marcado por diferentes propostas de desenho urbano, parte dos córregos Canela e Borá tiveram suas margens suprimidas e foram canalizados e fechados na década de 50 .

O trecho selecionado como área de estudo está delimitado pelas avenidas ao longo do eixo do córrego Canela. O eixo do córrego Canela localizase no centro da cidade de São José do Rio Preto. As avenidas Alberto Andaló e José Munia, marginais ao córrego, além de serem elementos importantes do sistema viário, abrigam um importante centro comercial e bancário. Na foto aérea da Figura 2 estão indicados os quatro pontos amostrais. Os pontos 1 e 2 na Av. Andaló; e 3 e 4 na Av. José Munia.

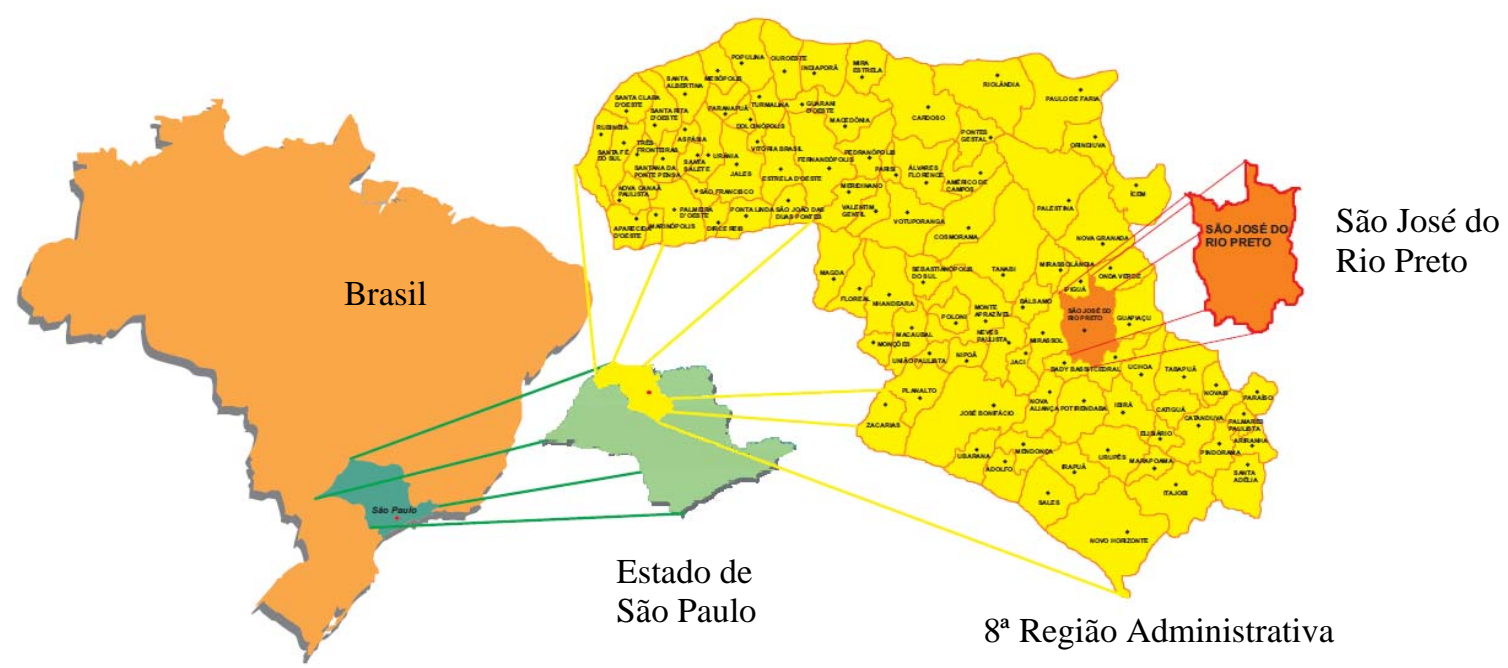

Figura 1 - Localização da cidade de São J osé do Rio Preto

Fonte: adaptado da Prefeitura Municipal de São J osé do Rio Preto (2008). 


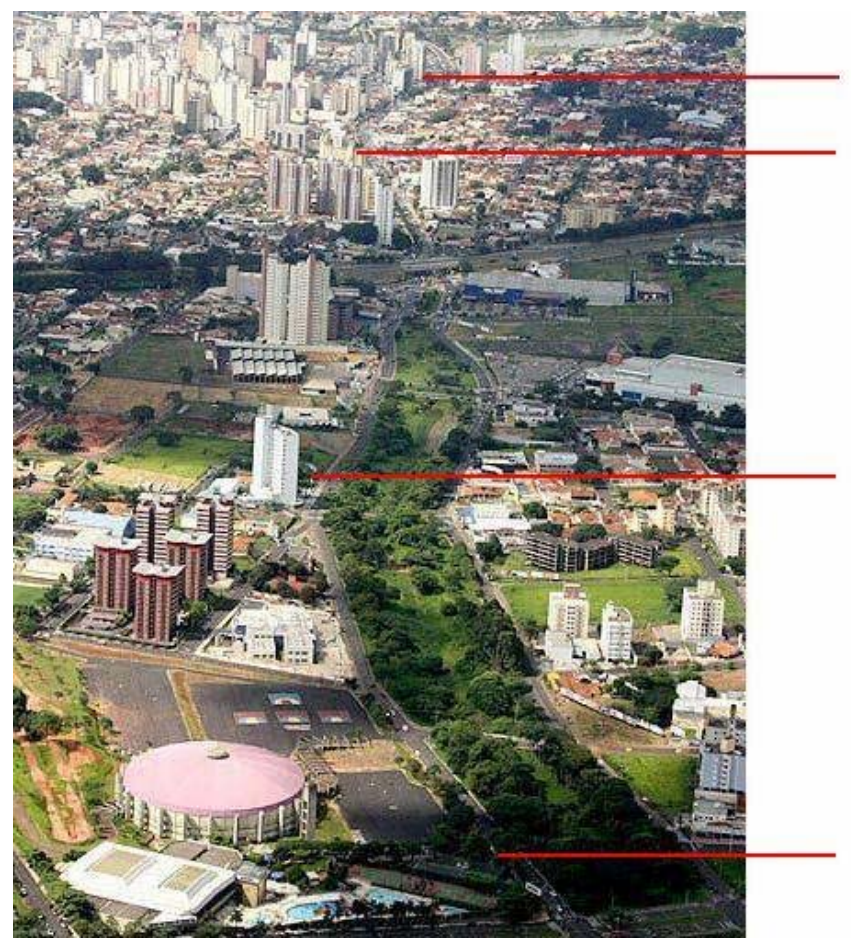

\author{
1 Edifício Residencial \\ 2 Condomínio Residencial \\ Paris Roma Rio
}

3 Hotel Saint Paul

4 SESC

Figura 2 - Pontos amostrais de 1 a 4 em vista aérea

Fonte: Prefeitura Municipal de São J osé do Rio Preto (2008).

Na mesma Figura 2, ao fundo, pode ser observada uma parte da represa municipal, e entre as duas avenidas é possível perceber que um viaduto eleva a Rodovia Washington Luis por sobre o córrego.

Além dos dados dos pontos amostrais, foram considerados dados de duas estações meteorológicas como referência:

(a) Companhia Ambiental do Estado de São Paulo - Cetesb ( COMPANHIA..., 2011); e

(b) Instituto Agronômico de Campinas - IAC (INSTITUTO..., 2011).

Esta última é considerada como estação rural para comparação com as temperaturas do ar nas áreas estudadas.

A estação da Cetesb (Figura 3) é uma estação de monitoramento automático. Tem o objetivo de avaliar a qualidade do ar urbano, disponibilizando ao público, pela internet, dados horários, diários e mensais, além de relatórios diversos, tanto de parâmetros meteorológicos como de níveis de poluentes presentes no ar. Nela, o equipamento utilizado é um termo-higrômetro, instalado a uma altura de 4,5 m em relação ao solo. A faixa de trabalho para temperatura do ar está entre $-30{ }^{\circ} \mathrm{C}$ e $70{ }^{\circ} \mathrm{C}$, com precisão de medida de $0,1{ }^{\circ} \mathrm{C}$, para mais ou para menos.
O IAC é um instituto de pesquisa da Agência Paulista de Tecnologia dos Agronegócios, da Secretaria de Agricultura e Abastecimento do Estado de São Paulo, com sede no município de Campinas. Entre as atividades desenvolvidas está o serviço prestado pelo Centro Integrado de Informações agrometeorológicas (Ciiagro). Esse operacionaliza e disponibiliza informações e aconselhamento às atividades agrícolas, com base nos parâmetros agrometeorológicos e na previsão do tempo, a partir de uma rede de coleta de dados em todo o estado.

O padrão da altura da medição nas estações do IAC é de aproximadamente $2 \mathrm{~m}$ acima da superfície vegetada. O sensor de temperatura e umidade utilizado é um HMP45, da Campbell, cuja faixa de medição de temperatura vai de -39,2 ${ }^{\circ} \mathrm{C}$ a $60{ }^{\circ} \mathrm{C}$, com precisão de $\pm 0,5^{\circ} \mathrm{C}\left(-40^{\circ} \mathrm{C}\right), \pm$ $0,4{ }^{\circ} \mathrm{C}\left(-20^{\circ} \mathrm{C}\right), \pm 0,3{ }^{\circ} \mathrm{C}\left(0^{\circ} \mathrm{C}\right), \pm 0,2^{\circ} \mathrm{C}\left(20^{\circ} \mathrm{C}\right), \pm$ $0,3^{\circ} \mathrm{C}\left(40^{\circ} \mathrm{C}\right)$ e $\pm 0,4{ }^{\circ} \mathrm{C}\left(60^{\circ} \mathrm{C}\right)$.

Diariamente os dados meteorológicos, através de um sistema web, são incorporados ao banco de dados. Os principais dados insertos são as temperaturas máximas e mínimas do ar e a precipitação diária. Além disso, os outros parâmetros da rede observacional estão disponíveis para consulta, análise e geração de produtos. 


\section{Caracterização morfológica nos pontos amostrais}

As áreas de abrangência dos quatro pontos de medição e da estação meteorológica da Cetesb foram caracterizadas por elementos espaciais de cobertura do solo. A partir dessas informações, observando que se trata de uma estimativa, foram calculadas taxas de cobertura e impermeabilização do solo em porcentagem da área total.

As taxas de cobertura do solo foram calculadas para os seguintes tipos de cobertura:

(c) pavimentação asfáltica;

(d) área ocupada por construção;

(e) área livre nas quadras; e

(f) canteiro ou várzea do córrego com vegetação.

Para o cálculo de permeabilidade do solo, foram considerados como áreas impermeáveis o pavimento asfáltico e as áreas ocupadas por construções, somadas a uma porcentagem da área livre das quadras, estimada em 30\% da área total das quadras, sendo $10 \%$ equivalente aos passeios e $20 \%$ equivalente à área de superfícies livres revestidas e impermeabilizadas nos lotes. Essa porcentagem foi definida tendo por base o estudo das proporções em uma das quadras. Como área permeável, consideraram-se a área livre descoberta nas quadras e os canteiros ou margens vegetados em ambas as avenidas.
Foram calculados a taxa de ocupação e o índice de utilização das quadras, com base na estimativa de área construída e número de pavimentos das edificações. Os passeios foram tratados como áreas livres das quadras ou como áreas de canteiros e várzea preservada.

\section{Coleta de dados térmicos}

Tendo como referência os quatro pontos amostrais, a coleta de dados térmicos foi feita com a instalação fixa de data-loggers, obedecendo às condições possíveis dentro dos seguintes parâmetros: possibilidade de instalação a uma altura de $2 \mathrm{~m}$ a $3 \mathrm{~m}$ e de $2 \mathrm{~m}$ a $3 \mathrm{~m}$ de distância do alinhamento; autorização dos responsáveis pelo imóvel; e segurança dos aparelhos.

Os sensores, data-loggers com proteção solar, conforme a Figura 4, fixados em postes metálicos, coletaram dados horários de 8 a 22 de abril de 2010.

A escolha da localização procurou garantir área livre com jardim frontal, sendo a distância entre o primeiro e o último ponto de 2,7 km (Figura 5). A estação de monitoramento automático da Cetesb localiza-se em área urbanizada bastante adensada, no Bairro Eldorado, e a estação do IAC em área mais afastada da ocupação urbana, no distrito de Engenheiro Schmidt.
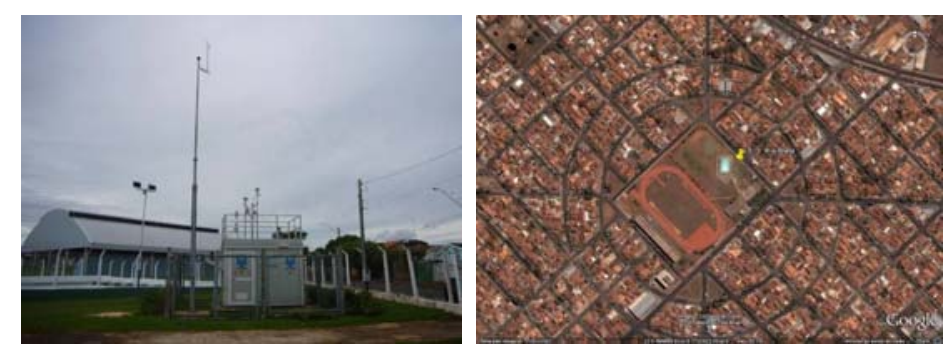

Figura 3 - Estação meteorológica da Cetesb em São J osé do Rio Preto

Fonte: Cetesb (2011).
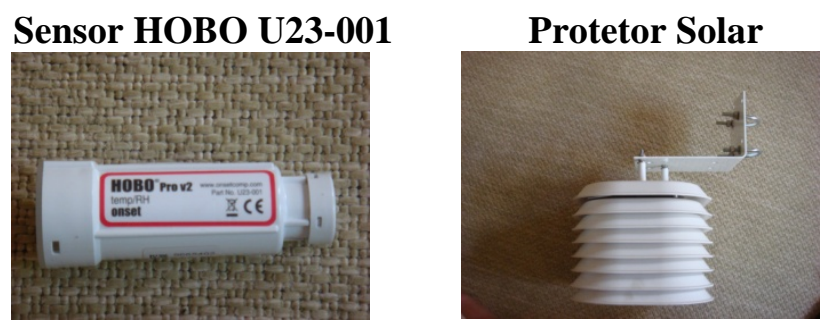

Especificações

Faixa de operação: $-40{ }^{\circ} \mathrm{C}$ a $70{ }^{\circ} \mathrm{C}$

Precisão: $0,2^{\circ} \mathrm{C}$ acima de $0{ }^{\circ} \mathrm{C}$ até $50{ }^{\circ} \mathrm{C}$

Resolução: $0,02{ }^{\circ} \mathrm{C}$ a $25^{\circ} \mathrm{C}$

Tempo de resposta:

$40 \mathrm{~min}$ no ar em movimento de $1 \mathrm{~m} / \mathrm{s}$

Figura 4 - Características dos sensores data-logger utilizados

166 Rocha, L. M. V.; Souza, L. C. L.; Castilho, F. J. V. 


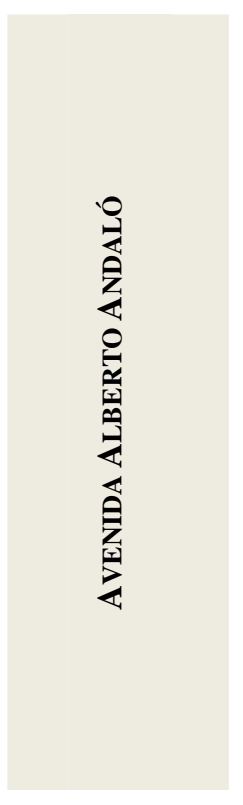

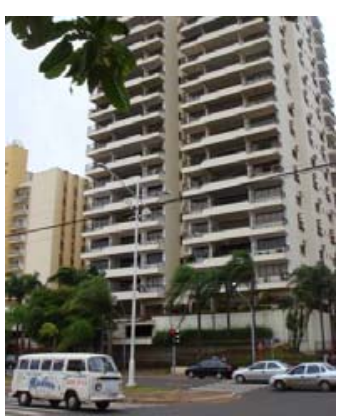

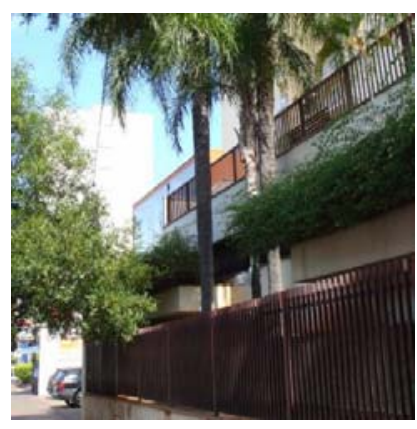

PONTO 2
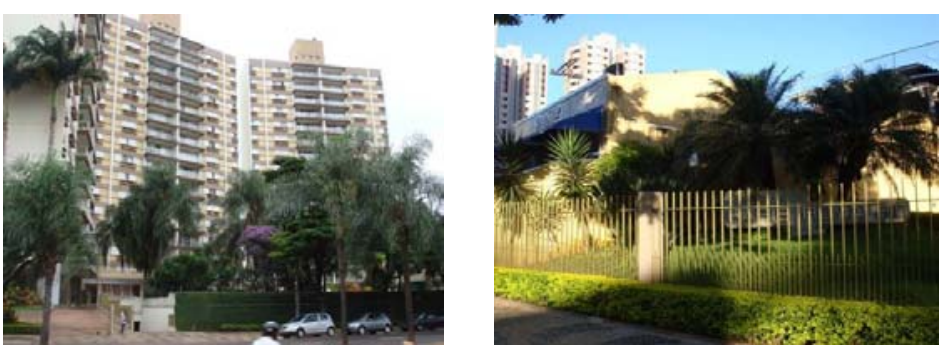
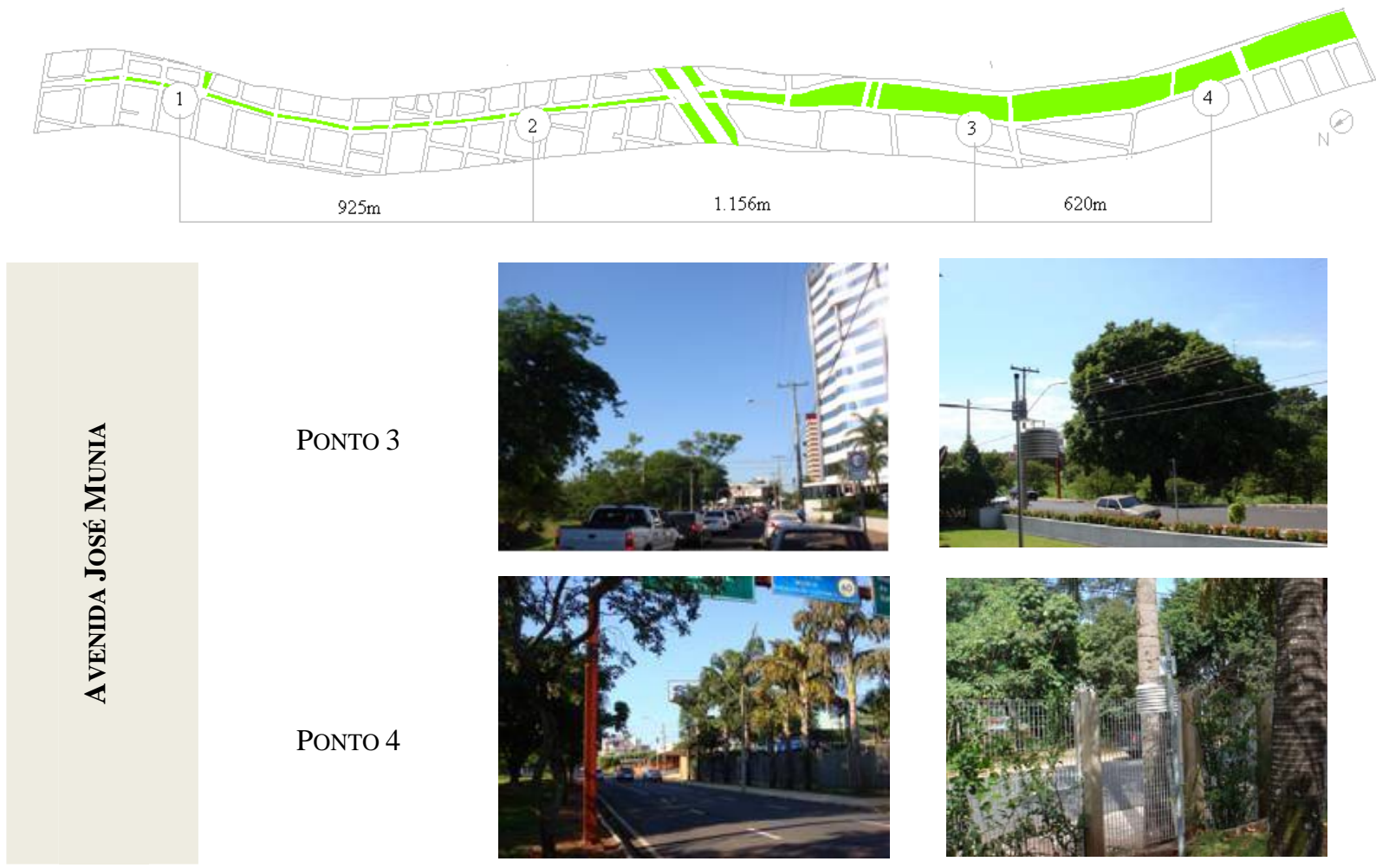

PONTO 3
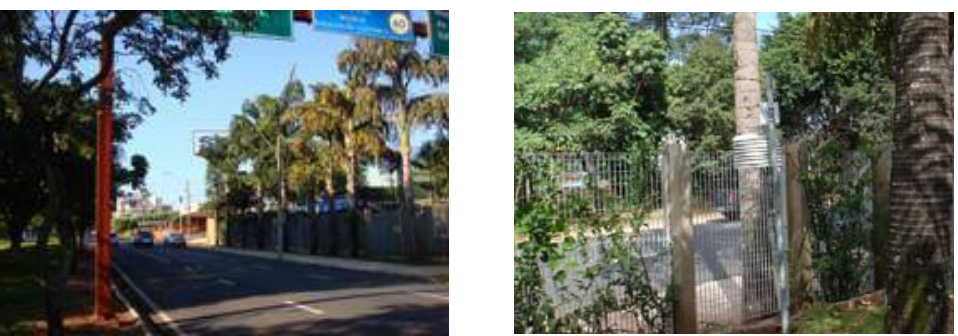

Figura 5 - Localização e fotos dos locais de medição de temperatura do ar

\section{Resultados}

Os principais resultados alcançados são aqui expostos para análise e discussão.

A Tabela 1 organiza comparativamente as variáveis de cobertura do solo em porcentagem da área total, permeabilidade do solo, taxa de ocupação e índice de utilização das quadras.
Além de possuir as maiores áreas verdes, os pontos 4 e 3, na Avenida José Munia, contam com a presença marcante de árvores nas margens do córrego. Os pontos 1 e 2, na Avenida Alberto Andaló, têm a maior área ocupada por construções e também a maior quantidade de prédios com 10 e 15 pavimentos. $\mathrm{O}$ ponto 3 tem apenas um prédio de 15 pavimentos. 
O período de medição foi marcado pela constante interação de dois sistemas atmosféricos, com céu claro em todos os dias:

(a) de 8 a 10 de abril observou-se a atuação da Massa Polar Atlântica (mPa); e

(b) do dia 10 ao 22 a Massa Tropical Atlântica (mTa) passou a atuar com força.

Nos dias de ação da mPa observaram-se temperaturas mais amenas durante todo o dia. Esse sistema atmosférico provoca também estabilidade atmosférica e, consequentemente, a presença constante da radiação solar. Nos dias de atuação da mTa verificaram-se, de maneira geral, temperaturas mais elevadas, sobretudo durante as tardes. Em geral, esse sistema atmosférico se caracteriza pela quase ausência de nebulosidade, temperaturas em elevação durante o dia e queda acentuada da umidade relativa do ar, sobretudo nos horários com temperaturas mais elevadas.

Nos dias 21 e 22 de abril, verificou-se a aproximação da frente polar atlântica (FPA). A aproximação desse sistema provoca um efeito chamado aquecimento pré-frontal, que é uma elevação das temperaturas que antecede a atuação da FPA. Como exemplo, pode-se citar o dia 21 de abril, quando por algumas vezes a temperatura superou os $33{ }^{\circ} \mathrm{C}$ durante o período da tarde, principalmente nos pontos com maior adensamento urbano. É importante ressaltar que o período de coleta passa pela fase de transição entre o verão e o inverno (outono). Dessa forma, verifica-se uma ausência de atuação de sistemas como a Zona de Convergência do Atlântico Sul, que é típico do período de verão. A máxima temperatura foi encontrada na estação de referência do IAC, 33,57 ${ }^{\circ} \mathrm{C}$, e a menor temperatura foi medida também na estação do IAC, $12,36{ }^{\circ} \mathrm{C}$. Na média, as temperaturas encontradas nos quatro pontos das avenidas no período apresentam pouca diferença.

Em todo o período de medição pode-se observar um comportamento diferenciado entre os períodos noturno e diurno. Durante o dia a temperatura nos pontos 1 e 2 foi pouco mais baixa que nos pontos 3 e 4. Durante a noite, a situação se inverteu: as temperaturas nos pontos 1 e 2 alcançaram valores mais altos que nos pontos 3 e 4 .

Com o pôr do sol, os pontos 3 e 4, com mais arborização e áreas livres, apresentaram as menores temperaturas. Já os pontos 1 e 2, mais ocupados por construções, foram os mais quentes à noite, a partir das $19 \mathrm{~h}$ e por toda a madrugada. Comparando o ponto 4 com o ponto 2, verificouse, nesse período, que a diferença foi maior no início da noite, alcançando $2{ }^{\circ} \mathrm{C}$, na maioria dos dias, e mais de $3{ }^{\circ} \mathrm{C}$ em alguns dias (Figura 6).

Tabela 1 - Ocupação do solo nas áreas estudadas

\begin{tabular}{lccccc}
\hline Taxa de cobertura do solo & Ponto 1 & Ponto 2 & Ponto 3 & Ponto 4 & Cetesb \\
\hline Pavimentação asfáltica & $34 \%$ & $33 \%$ & $22 \%$ & $23 \%$ & $20 \%$ \\
\hline Canteiro ou várzea com vegetação & $3 \%$ & $3 \%$ & $26 \%$ & $27 \%$ & $0 \%$ \\
\hline Área construída & $27 \%$ & $21 \%$ & $4 \%$ & $3 \%$ & $24 \%$ \\
\hline Área livre nas quadras & $37 \%$ & $44 \%$ & $45 \%$ & $45 \%$ & $55 \%$ \\
\hline Passeios e quintais revestidos & $19 \%$ & $19 \%$ & $15 \%$ & $14 \%$ & $24 \%$ \\
\hline Quintais permeáveis & $17 \%$ & $24 \%$ & $31 \%$ & $30 \%$ & $31 \%$ \\
\hline Permeabilidade do solo & $20 \%$ & $27 \%$ & $57 \%$ & $58 \%$ & $31 \%$ \\
\hline Taxa de ocupação das quadras & $43 \%$ & $32 \%$ & $7 \%$ & $6 \%$ & $31 \%$ \\
\hline Índice de utilização das quadras & 2,4 & 1,5 & 0,5 & 0,3 & 0,6 \\
\hline
\end{tabular}

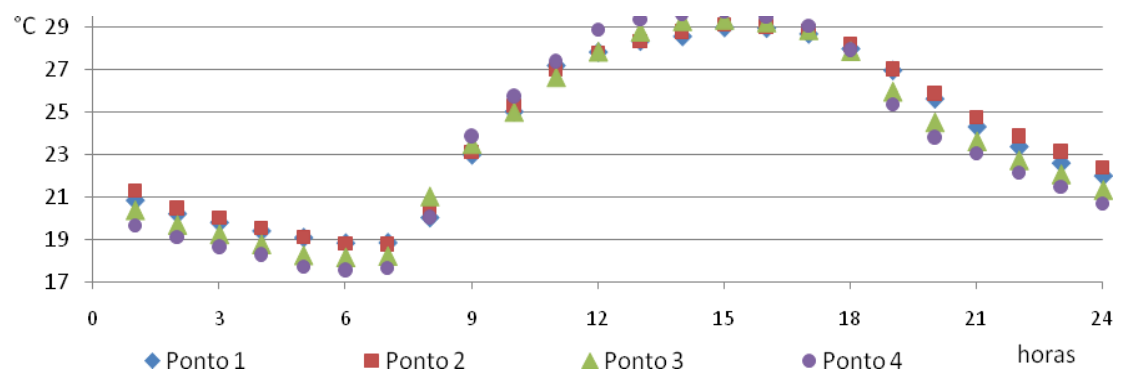

Figura 6 - Média horária das temperaturas nos pontos amostrais

168 Rocha, L. M. V.; Souza, L. C. L.; Castilho, F. J. V. 
Quando comparada a temperatura do ar nas áreas estudadas, verificou-se que, durante o dia, no ponto 4 a temperatura é a mais elevada, na maioria das vezes, das $8 \mathrm{~h}$ às $17 \mathrm{~h}$, e no ponto 2 a temperatura é mais elevada das $19 \mathrm{~h}$ às $7 \mathrm{~h}$ da manhã. As temperaturas mais baixas à noite foram encontradas nos pontos 4 e 3 ; e durante o dia no ponto 1 na maioria das vezes, e em alguns horários no ponto 2.

Comparando a média horária da diferença da temperatura do ar entre os pontos mais aquecidos e os mais resfriados nas avenidas, tem-se que a diferença durante o dia fica em $0,8{ }^{\circ} \mathrm{C}$ na média, enquanto a diferença no período noturno fica em $1,5^{\circ} \mathrm{C}$ na média.

Na análise da variação horária da temperatura do ar, verificou-se que as temperaturas mais baixas ocorreram por volta das $7 \mathrm{~h}$, em todos os dias para todos os pontos. No intervalo entre as $7 \mathrm{~h}$ até as 16h, as áreas ganham calor devido à incidência solar. Entre $8 \mathrm{~h}$ e $12 \mathrm{~h}$, observaram-se as maiores diferenças entre as taxas de aquecimento nas áreas (Tabela 2).
Os pontos com as maiores taxas de aquecimento foram a estação de referência do IAC e o ponto 4 . A estação do IAC apresentou a taxa de aquecimento mais alta entre $8 \mathrm{~h}$ e $9 \mathrm{~h}$, com valor de $4{ }^{\circ} \mathrm{C} / \mathrm{h}$. Nesse mesmo horário o ponto 4 foi o que mais se aproximou desse valor, com taxa de 3,8 ${ }^{\circ} \mathrm{C} / \mathrm{h}$. São pontos com mais áreas livres, que ganham gradativamente mais calor, acumulando um ganho das $8 \mathrm{~h}$ às $12 \mathrm{~h}$, com médias de $12{ }^{\circ} \mathrm{C}$ e $11^{\circ} \mathrm{C}$ respectivamente. Os pontos 1 e 2 ganharam menos calor a cada hora, acumulando aproximadamente $9^{\circ} \mathrm{C}$ das $8 \mathrm{~h}$ às $12 \mathrm{~h}$ (Figura 7).

As temperaturas mais altas ocorreram, em geral, entre $15 \mathrm{~h}$ e $16 \mathrm{~h}$, para todos os dias em todos os pontos. Ao cair da tarde, verificou-se diferença nas taxas de resfriamento nos pontos, quase nas mesmas proporções que o aquecimento. A partir das $18 \mathrm{~h}$, a perda de calor aumenta, e as taxas de resfriamento mais altas foram encontradas também na estação de referência do IAC, seguida pelo ponto 4 (Tabela 3).

Tabela 2 - Média horária da taxa de aquecimento nos pontos ( ${ }^{\circ} \mathrm{C} /$ hora)

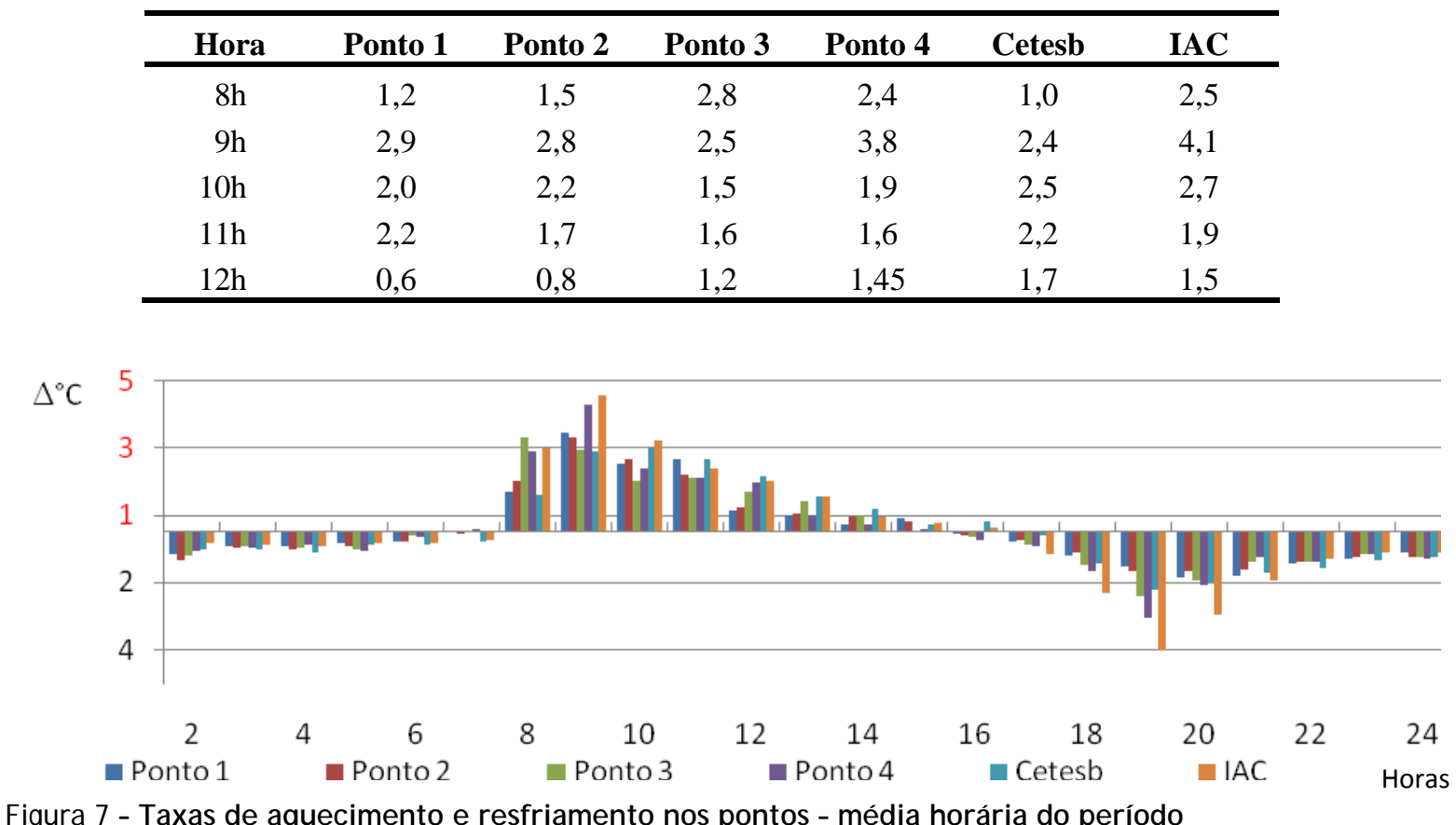

Figura 7 - Taxas de aquecimento e resfriamento nos pontos - média horária do período 
Tabela 3 - Taxa de resfriamento nos pontos (ㄷ/hora) - média horária nos pontos

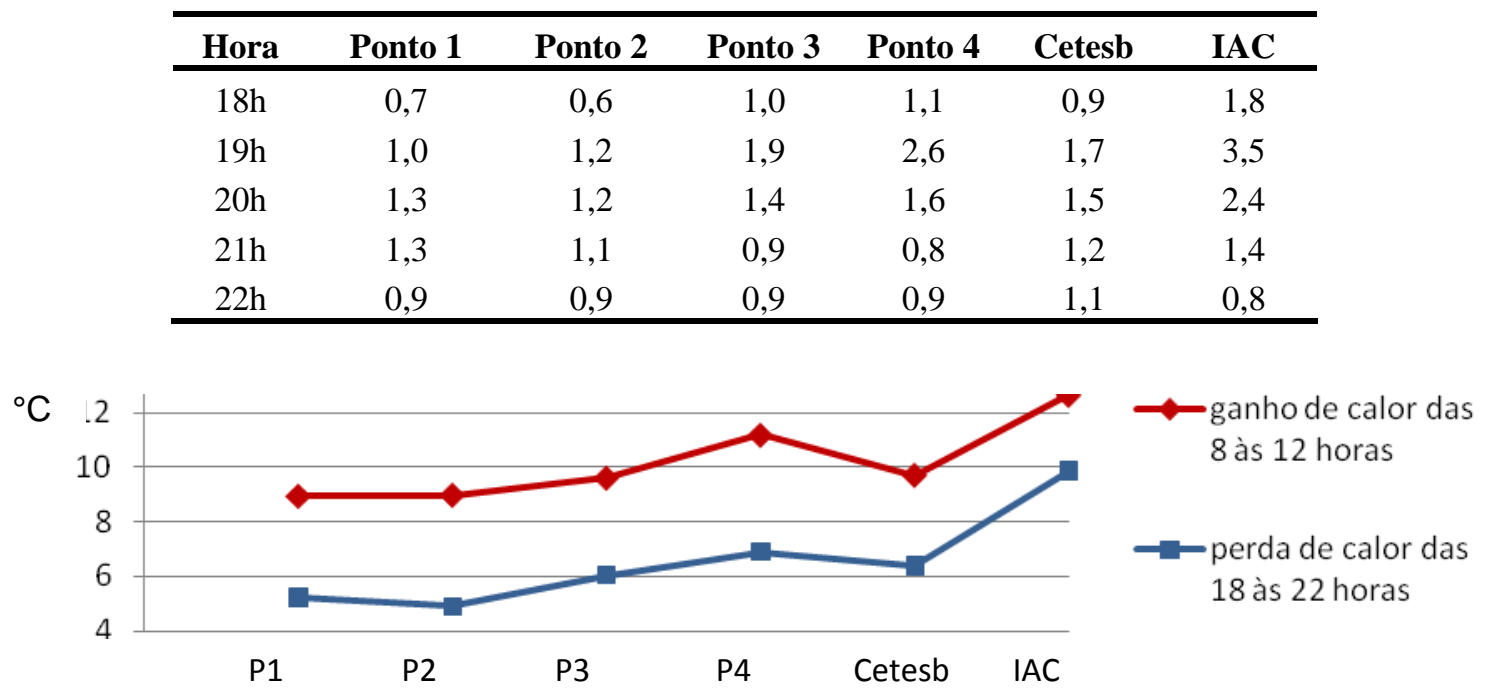

Figura 8 - Ganho e perda de calor nas áreas no período de 8 a 22 de abril

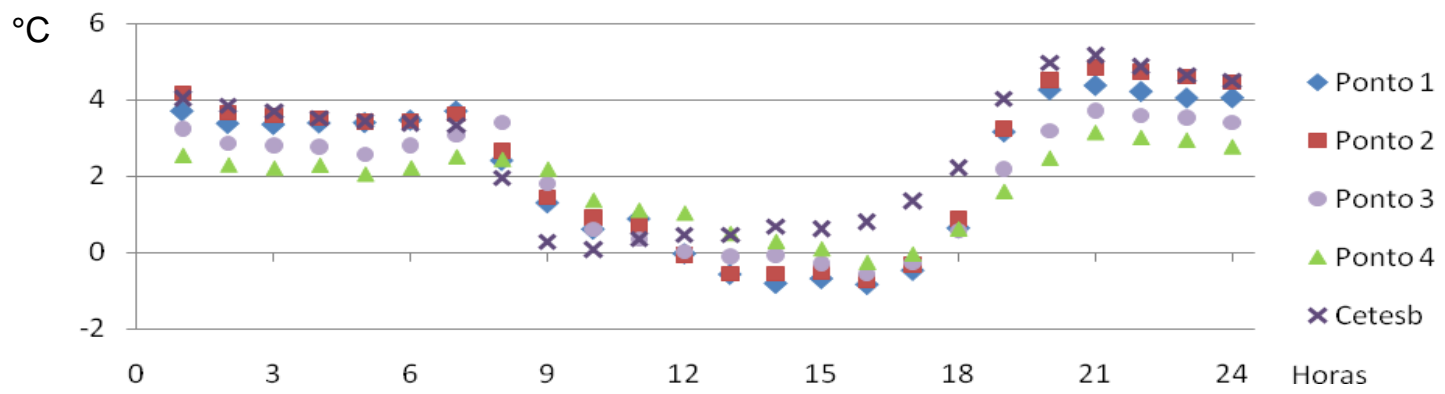

Figura 9 - Média horária da diferença térmica em relação à estação rural nos pontos

Nos pontos 1 e 2, com o solo mais pavimentado e ocupado por construções, a taxa de resfriamento foi menor. Entre $18 \mathrm{~h}$ e $19 \mathrm{~h}$, quando a estação do IAC apresentou a maior taxa de resfriamento, com perda de $3,5{ }^{\circ} \mathrm{C} / \mathrm{h}$, a taxa do ponto 4 foi de 2,6 ${ }^{\circ} \mathrm{C} / \mathrm{h}$. Portanto, a taxa de resfriamento do ponto 4 foi mais alta em $1,6{ }^{\circ} \mathrm{C} / \mathrm{h}$ que o ponto $1,1,4^{\circ} \mathrm{C}$ que o ponto 2 e $0,7^{\circ} \mathrm{C}$ que o ponto 3 nesse horário. Em média, a diferença de perda de calor acumulada das $18 \mathrm{~h}$ às $22 \mathrm{~h}$ entre a estação do IAC e o ponto 4 é de aproximadamente $3{ }^{\circ} \mathrm{C}$, e entre o ponto 4 e o ponto 2, de $2{ }^{\circ} \mathrm{C}$ (Figura 8).

Em todos os dias configurou-se nas áreas de estudo uma ilha de calor no período noturno. Durante o dia, em geral, as temperaturas nos pontos de medição são bem próximas entre si. Seus valores se aproximam ao da estação de referência do IAC das $10 \mathrm{~h}$ às $18 \mathrm{~h}$, chegando a ser menores das $12 \mathrm{~h}$ às $17 \mathrm{~h}$ nos pontos 1,2 e 3 . A
Figura 9 mostra a variação horária média das diferenças térmicas entre área urbana e rural nos pontos de medição e estação Cetesb.

Considerando a média dos valores horários da temperatura do ar diurnos, das $7 \mathrm{~h}$ às $19 \mathrm{~h}$, e noturnos, das $19 \mathrm{~h}$ às $7 \mathrm{~h}$, verifica-se que há diferença térmica entre a estação rural e as áreas estudadas nos dois períodos. Durante o dia a intensidade dessas diferenças nas áreas estudadas difere em menos de $0,5^{\circ} \mathrm{C}$, sendo o ponto 4 o mais aquecido. À noite essa diferença de intensidade entre as áreas estudadas aumenta para $1,5{ }^{\circ} \mathrm{C}$, sendo o ponto 4 o mais resfriado.

Na área da Cetesb a diferença de temperatura do ar com a estação de referência do IAC foi maior nos dois períodos. Essa pequena diferença pode ter ocorrido em função da diferença de padrão na coleta de dados (Figura 10). 


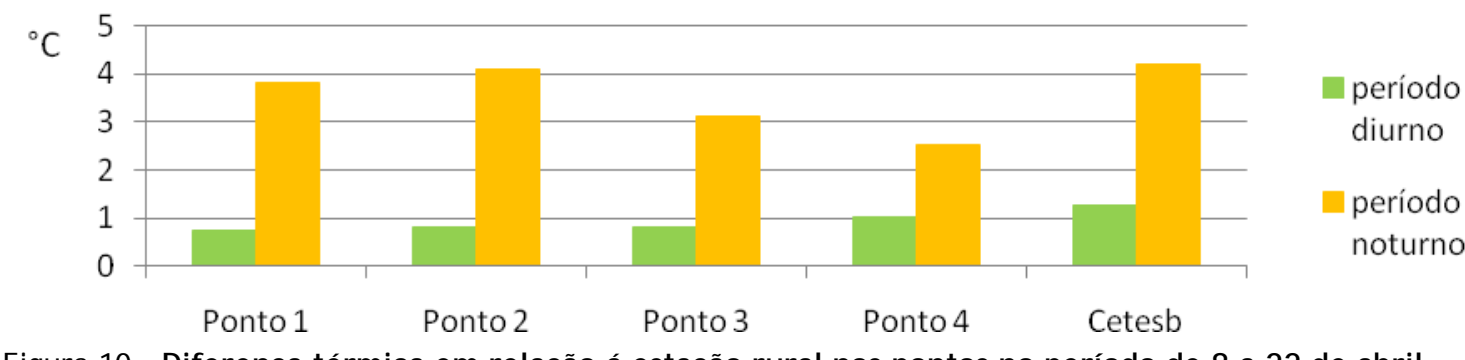

Figura 10 - Diferença térmica em relação á estação rural nos pontos no período de 8 a 22 de abril
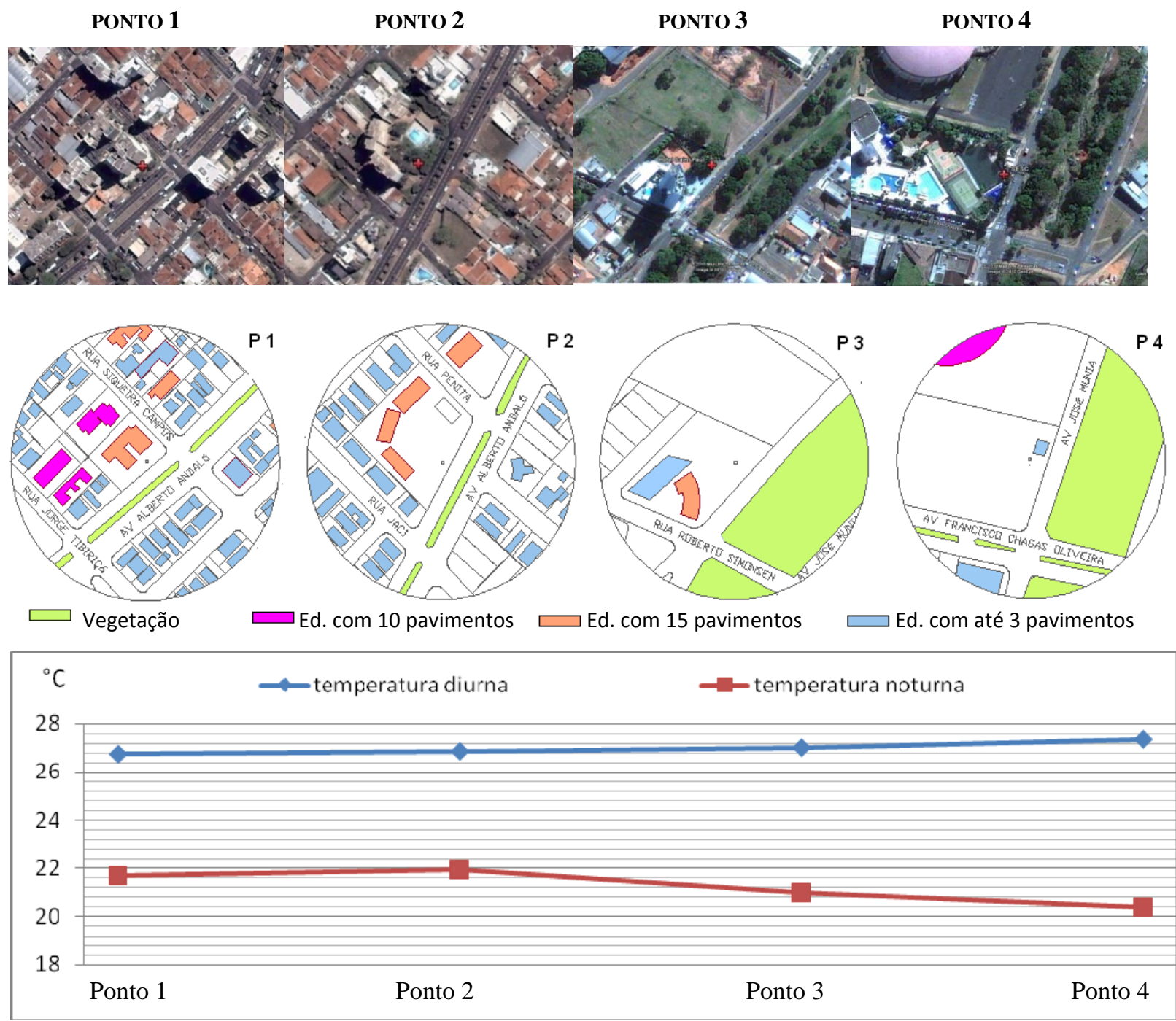

Figura 11 - Ocupação do solo e temperatura do ar nas áreas dos quatro pontos amostrais

\section{Análise dos resultados}

O quadro da Figura 11 faz uma exposição geral dos resultados obtidos com a caracterização das áreas nas avenidas e os resultados encontrados para as temperaturas médias do ar, considerando todos os dias de medição nos períodos diurno e noturno. O período noturno apresentou diferença mais significativa entre as temperaturas do ar registradas nas áreas estudadas de 8 a 22 de abril. Nesse período as temperaturas do ar mais baixas foram encontradas nos pontos 3 e 4 . Esses são pontos na Avenida José Munia, onde existem mais superfícies livres e também mais áreas cobertas por vegetação com espécies arbóreas de médio e grande portes. 
A maior diferença térmica em relação à estação rural à noite expressa a diferença na capacidade de dissipação do calor acumulado entre as áreas estudadas. O quadro exposto na Figura 12 demonstra um resumo dos resultados da relação entre essas diferenças térmicas noturnas, o perfil das áreas e a cobertura do solo. Percebe-se que a diferença térmica é menor nos pontos 3 e 4, mais

Perfil das áreas

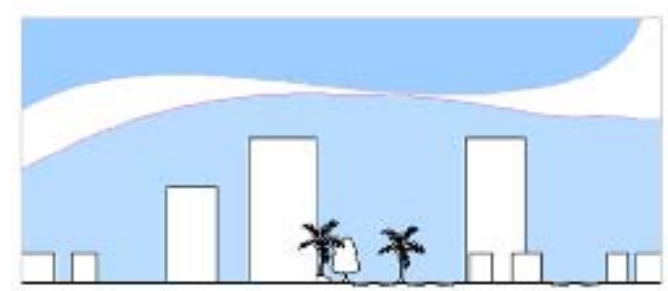

Ponto 1

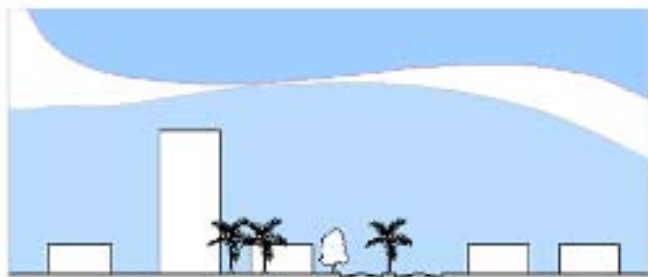

Ponto 2

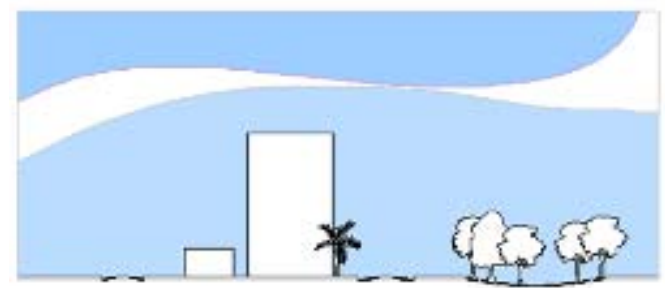

Ponto 3

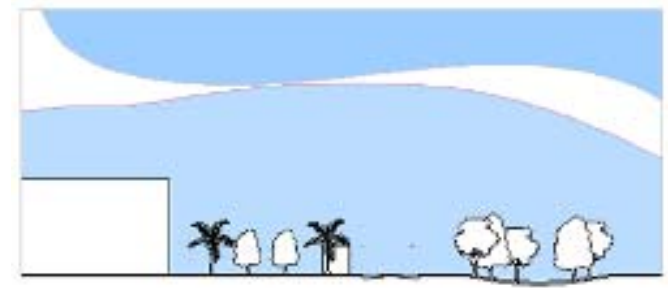

Ponto 4

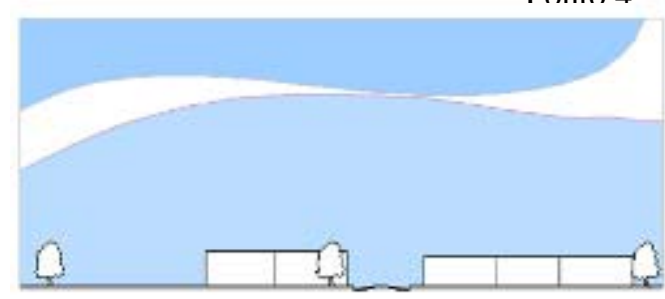

CETESB arborizados e com uma ocupação menor do solo. Nos pontos 1 e 2, a diferença é maior. Embora a estação da Cetesb não possa ser comparada aos quatro pontos amostrais das avenidas, por não apresentar o mesmo padrão de coleta de dados, nota-se que essa diferença é um pouco maior que nos pontos 1 e 2 .

* Vegetação

= Permeabilidade do solo

* Área construída

* Diferença

= Pavimentação asfáltica térmica em relação à estação

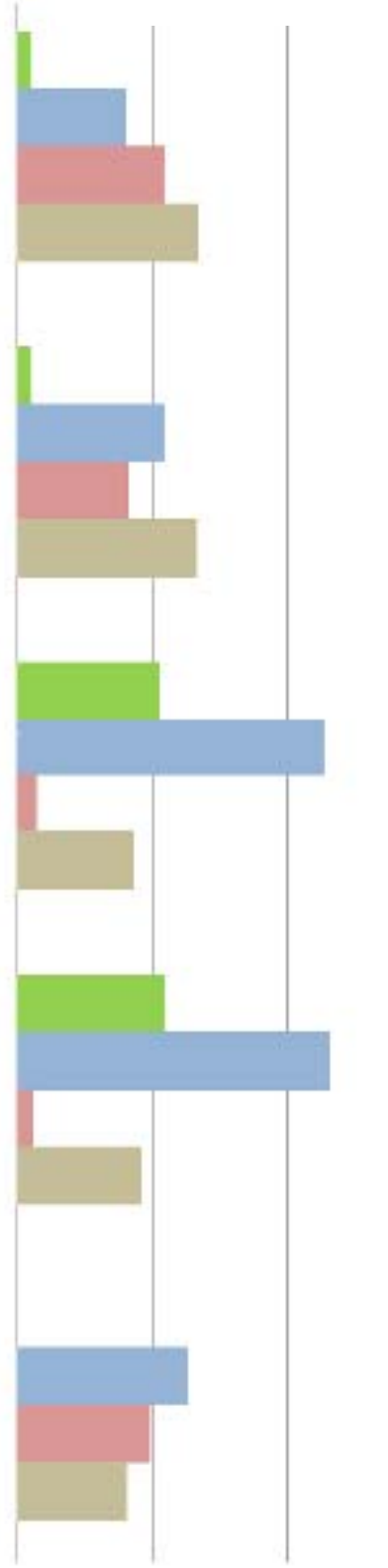

rural
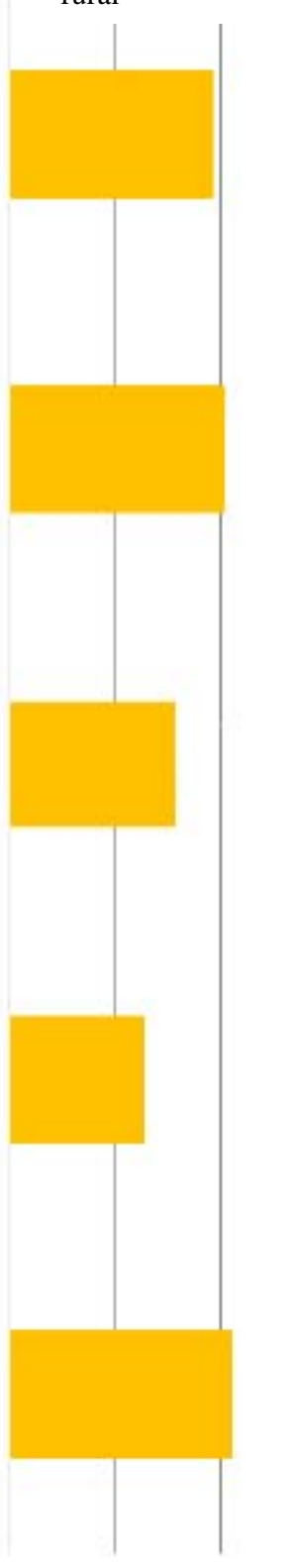

$0 \%$

$25 \%$

$50 \%$

0

2

$4{ }^{\circ} \mathrm{C}$

Figura 12 - Perfil, cobertura do solo e diferença térmica nas áreas em relação à estação rural 
Tabela 4 - Quadro-resumo da correlação e tendência do comportamento da temperatura noturna em relação ao incremento dos parâmetros urbanos

\section{Variáveis de cobertura do solo Coeficiente de correlação (R) Tendência *}

\begin{tabular}{lll}
\hline Superfícies cobertas com vegetação & 0,94 & 0,89 \\
Superfícies asfaltadas & 0,90 \\
Superfícies permeáveis & 0,95 \\
Superfícies pavimentadas nas quadras & 0,88 & 0 \\
Taxa de ocupação das quadras & 0,88 & \} \\
Superfícies ocupadas com construções & & \}
\end{tabular}

Nota: Legenda: $\left\{\begin{array}{l}\text { tendência de elevação da temperatura noturna } \\ \text { tendência de queda da temperatura noturna }\end{array}\right.$

Apesar da limitação do número de pontos amostrais, realizou-se uma análise para simples verificação da tendência de comportamento das temperaturas noturnas em relação aos parâmetros urbanos nas quatro áreas das avenidas em estudo. Os resultados dessas tendências são apresentados na Tabela 4. Nela o coeficiente de correlação está relacionado a cada um dos parâmetros, e as setas indicam a elevação ou queda da temperatura do ar.

\section{Relação das características de cobertura do solo com a temperatura do ar}

O período de medição caracterizou-se pela quase ausência de nebulosidade, temperaturas em elevação durante o dia e queda acentuada da umidade relativa do ar, sobretudo nos horários com temperaturas mais elevadas. A presença constante da radiação solar agindo sobre a camada urbana provoca maior diferenciação térmica entre as áreas com muitas edificações e as áreas com menos edificações e menor impermeabilização do solo.

Na análise da relação entre as características de cobertura do solo com a temperatura do ar e as diferenças térmicas noturnas, a presença de vegetação e a permeabilidade do solo contribuíram para amenizar as temperaturas à noite. As superfícies revestidas e as construções contribuíram para diminuir a perda de calor. Nesse período as temperaturas mais baixas foram encontradas na Avenida José Munia, nos pontos 3 e 4, que têm mais áreas livres e uma vegetação significativa.

Porém, ao contrário do que se poderia esperar, a correlação dos dados não demonstrou que a maior quantidade de áreas vegetadas ajudasse a amenizar a temperatura do ar no período diurno. Uma possibilidade é que a sombra propiciada pela vegetação presente nessas áreas não tenha atingindo todas as superfícies livres do solo, pavimentadas ou não, permitindo que a insolação direta aquecesse o ar imediato.

Por outro lado, os maiores valores do coeficiente de correlação (R) obtidos para a temperatura diurna estão relacionados à área ocupada por construções, à taxa de ocupação e ao índice de utilização. Esses refletem a maior densidade construída por metro quadrado de superfície do solo. Os resultados sugerem que, no período de insolação, o sombreamento proporcionado pela maior área construída e prédios altos nos pontos 1 e 2 da Avenida Andaló leve a um menor aquecimento dessas áreas.

Quando o sol se põe, as áreas perdem calor em maior ou menor quantidade, conforme as características do ambiente. Quanto maior a presença de materiais que absorvem calor, mais lentamente a área perde o calor acumulado. Isso fez com que as áreas de abrangência dos pontos $1 \mathrm{e}$ 2 , mais densamente ocupadas, armazenassem mais calor à noite.

Incluindo a área da estação de referência da Cetesb na análise, observou-se que as características que mais contribuem para amenizar a temperatura noturna, minimizando a diferença térmica entre área urbana e rural, foram a vegetação e a permeabilidade do solo. Além disso, a pavimentação das quadras e a área ocupada por construções foram identificados como fatores 
importantes, que contribuem para o acúmulo de calor e a intensificação das diferenças térmicas noturnas.

\section{Considerações finais}

O estudo demonstrou uma diferenciação do comportamento térmico das áreas estudadas ao longo do eixo do córrego Canela em dois grupos. Em um estão as áreas dos pontos 1 e 2, na Av. Alberto Andaló; em outro, as áreas dos pontos 3 e 4, mais arborizados, na Av. José Munia.

A análise possibilitou verificar a influência direta da vegetação e permeabilidade do solo na amenização do armazenamento de calor noturno. Verificou-se também que a maior área ocupada por construções, a maior massa construída e a maior pavimentação foram características que contribuíram para a menor perda de calor após o pôr do sol.

Durante o dia, na Avenida Andaló, as temperaturas encontradas foram um pouco mais baixas onde a área construída e a altura dos edifícios são maiores. Isso ocorre, provavelmente, devido à sombra propiciada pelos edifícios altos ao longo da avenida. Na Avenida José Munia, embora haja ocorrência de maior vegetação, esta se limita à margem do córrego, havendo nas quadras mais áreas livres (revestidas ou não). As correlações sugerem que essas áreas recebem uma incidência solar direta nas superfícies e, pela falta de sombreamento, aquecem o ar das áreas imediatas.

Os resultados aqui encontrados reforçam as diferenças de comportamento térmico em áreas urbanas, entre os períodos diurno e noturno, também encontradas por Gomes e Lamberts (2009), Saaroni et al. (2000) e Chen-Yi et al. (2009). A contribuição das áreas vegetadas como elemento de minimização das temperaturas do ar foi verificada de forma mais significativa no período noturno. Nesse período também se verificou o atraso na perda de calor nas áreas com superfícies impermeabilizadas e maior densidade construída.

Para aqueles mesmos autores, as influências de ventos e da radiação direta justificam o fato de a vegetação não desempenhar um papel mais importante na amenização da temperatura do ar durante o dia. Em algumas áreas pode haver maior dissipação do calor pela movimentação do ar ou proteção da insolação por sombreamento, compensando as diferenças de comportamento térmico entre áreas quanto ao adensamento, impermeabilização e presença de vegetação. Contudo, os resultados aqui encontrados permitem apenas apontar a existência de uma tendência para o comportamento das áreas estudadas. Isso se repete mesmo quando os dados e as características da área da estação da Cetesb são acrescentados à análise de correlação. Dessa forma, a pesquisa confirmou a existência da influência térmica das características urbanas, apontando a tendência de amenização do armazenamento de calor noturno pela presença da vegetação e permeabilidade do solo. Além disso, verificou-se a tendência de haver maior armazenamento de calor noturno nas áreas onde há maior área construída e mais superfícies pavimentadas.

Os resultados encontrados evidenciam a necessidade de equilíbrio quanto ao uso e ocupação do solo. Apontam que há possibilidade de promoção do controle da incidência solar com o sombreamento das superfícies, seja com elementos construídos ou arborização urbana. Ressalta-se, no entanto, que a arborização mostrou-se mais eficiente como elemento de amenização do armazenamento de calor noturno.

\section{Referências bibliográficas}

ABREU, L. V.; LABAKI, L. C. Conforto Térmico Propiciado por Algumas Espécies Arbóreas: avaliação do raio de influência através de diferentes índices de conforto. Ambiente Construído, Porto Alegre, v. 10, n. 4, p. 103-117, out./dez. 2010.

BARBOSA, R. V. R.; BARBIRATO, G. M.; VECCHIA, F. A. S. Vegetação Urbana: análise experimental em cidade de clima quente e úmido. Curitiba: ENCAC- COTEDI, 2003.

CASTILHO, F. J. V. Abordagem Geográfica do Clima Urbano e das Enfermidades em São José do Rio Preto, SP. 2006. Dissertação (Mestrado em Geografia) - Faculdade de Geografia, Universidade Estadual Paulista, Rio Claro, 2006.

CHEN-YI S. et al. A Thermal Environment Investigation of the Urban Street Canyon in a Hot and Humid City, Taichung City, Taiwan. In: INTERNATIONAL CONFERENCE ON URBAN CLIMATE, 7., Yokohama, Japan, 2009. Anais... Yokohama, Japan, 2009.

COMPANHIA AMBIENTAL DO ESTADO DE SÃO PAULO. Sistema de Informação de Qualidade do Ar. Disponível em: <http://www.cetesb.sp.gov.br/Ar/ar_qualar.asp>. Acesso em: 22 ago. 2011. 
DACANAL, C. et al. Microclima em Fundos de Vale: análise de diferentes ocupações urbanas em Campinas, SP. In: ENCONTRO NACIONAL DE TECNOLOGIA DO AMBIENTA CONSTRUÍDO, 12.,. Fortaleza, 2008. Anais... Fortaleza: Antac, 2008.

DUARTE, D. H. S. Variáveis Urbanísticas e Microclimas Urbanos: modelo empírico e proposta de um indicador. Revista Forum Patrimônio, v. 3, n. 2, p. 1-22, 2009.

EMMANUEL, M. R. An Urban approach to Climate: sensitive design. London: Spon Press, Londres, 2005.

GOMES, P. S.; LAMBERTS, R. O Estudo do Clima Urbano e a Legislação Urbanística: considerações a partir do caso de Montes Claros, MG. Ambiente Construído, Porto Alegre, v. 9, n. 1, p. 73-91, jan./mar. 2009.

INSTITUTO AGRONÔMICO DE CAMPINAS. CIIAGRO: Centro Integrado de Informações Agrometeorológicas. Disponível em: $<$ http://www.ciiagro.sp.gov.br/rede.html>. Acesso em: 22 ago. 2011.

OKE, T. R. Initial Guidance to Obtain Representative Meteorological Observations at Urban Site, Instruments and Methods of Observation Program. IOM Report No 81, WMO/TD 1250, p. 1-33, World Meteorological Organization, 2006.

PARKER, D. Urban Heat Island Effects on Estimates of Observed Climate Change. Interdisciplinary Review, London, v. 1, n. 1, p. 123-133, 2010.
PREFEITURA MUNICIPAL DE SÃO JOSÉ DO RIO PRETO. Secretaria de Planejamento e Gestão Estratégica Municipal, São José do Rio Preto.Conjuntura Econômica de São José do Rio Preto. São José do Rio Preto: PMSJRP, 2008.

SAARONI, H. et al. Spatial Distribution and Microscale Characteristics of the Urban Heat Island in Tel-Aviv, Israel. Landscape and Urban Planning, v. 48, n. 1/2, p. 1-18, 2000.

SILVA, C. F.; ROMERO, M. A. B. O Desempenho Ambiental de Vias Arborizadas na Cidade de Teresina por Meio de Dados Sensoriais, Microclimáticos e Computacionais Com o Auxílio do ENVI-Met. In: ENCONTRO NACIONAL DE CONFORTO NO AMBIENTE CONSTRUÍDO, Natal, 2009. Anais... Natal: Antac, 2009. p. 573582.

SCUSSEL, M. C. B.; SATTLER, M. A. Cidades em (Trans)Formação: impacto da verticalização e densificação na qualidade do espaço residencial. Ambiente Construído, Porto Alegre, v. 10, n. 3, p. 137-150, jul./set. 2010.

SOUZA, L. C. L. et al. Fator de Visão do Céu e Intensidade de Ilhas de Calor na Escala do Pedestre em Uma Fração Urbana de Bauru, SP. In: ENCONTRO NACIONAL E VI ENCONTRO DA AMÉRICA LATINA DE CONFORTO NO AMBIENTE CONSTRUÍDO, 10., Natal, 2009. Anais... Natal: Antac, 2009. p. 182-189.

\section{Agradecimentos}

Os autores agradecem à CAPES, pela bolsa concedida à pesquisadora mestranda.

Revista Ambiente Construído

Associação Nacional de Tecnologia do Ambiente Construído

Av. Osvaldo Aranha, 99 - 3o andar, Centro

Porto Alegre - RS - Brasil CEP 90035-190

Telefone: +55 (51) 3308-4084 Fax: +55 (51) 3308-4054

www. seer. ufrgs. br/ ambienteconstruido

E-mail: ambienteconstruido@ufrgs.br 